\title{
Quality of agricultural-food products as a factor of the Republic of Serbia's competitiveness in international market
}

\author{
Milojević Ivan ${ }^{1}$, Cvijanović Drago $^{2 \star}$ and Cvijanović Gorica ${ }^{3}$ \\ ${ }^{1}$ University for Business Studies, Banja Luka, 23a Jovana Dučića Street, 78000 Banja Luka, Republic of Srpska, Bosnia \\ and Herzegovina. \\ ${ }^{2}$ Principal Research Fellow, Institute of Agricultural Economics, Belgrade, Volgina 15, Serbia. \\ ${ }^{3}$ Faculty of Biofarming, Sombor University, Serbia.
}

Accepted 20 June, 2011

\begin{abstract}
This study analyzes the competitiveness of agricultural-food products of Serbia in the local and international markets. The subject of this research is analysis of relevant competitiveness factors of agricultural-food products, aiming to assess the products' quality and highlight the main intentions of production and processing. Possibility of improving the products' quality was also considered. In this study, we started from the hypothesis that Serbia has the potential to produce and process high-quality products for the local market and export. It is possible to strengthen economy competitiveness and improve product quality by increasing productivity, efficiency and economy in production, and by applying actual knowledge, technologies and experiences.
\end{abstract}

Key words: Quality of products, competitiveness of Serbian agricultural products, agricultural products' market.

\section{INTRODUCTION}

Competitiveness is a base for success in the local, but especially in the international market. Competition encourages manufacturers and processors of agricultural products to offer a high-quality product, to reduce costs in relation to the competitive one, and to decide on a product, products line or services in accordance with customer wishes and needs. The competitiveness factors are numerous and they affect the producer's competitiveness, organizations and states, and accent is put on quality of products and services, quality standards, food safety and the environment protection. In order to manufacture products of higher quality, producers and processors need to explore new markets, develop new products and invest in new technologies in order to produce high-final products for the local market needs and export dynamism (Babovic and Lazić, 2005). Based on market analysis, assessment of the possibility to expand and conquer new markets should be made,

*Corresponding author. E-mail: drago_c@mail.iep.bg.ac.rs. Tel: 2972-848. to know better potential competition and to direct foreign exchange earnings to import of high-quality scarce inputs for the local production needs and development of highquality assortment intended for export.

\section{AGRICULTURAL PRODUCTION COMPETITIVENESS}

Serbia has favourable agro-ecological conditions for development of plant production. However, natural diversity, size of property, ownership structure, differences in soil fertility, pollution and changes of soil's physical and chemical characteristics, insufficient use of high-yield crops, and lack of agro-technical measures' application had affected production extensification. Unstable economic conditions and transition also led to reduction and change in production size and structure. Reduction of physical volume in production resulted to long-term unfavourable position in primary and secondary distribution, due to reduced prices of agricultural products and price disparities of industrial inputs and agrarian products (Babovic, 2008). The system of financing and credit policy is inadequate and non-adjusted to needs of 
agricultural production. Low accumulative and reproductive potentials of husbandries, agricultural cooperatives and companies along with lack of some raw materials caused decline in technical-technological level and crop production extensification.

Serbia has comparative natural conditions for production of healthy-safe and competitive products of animal origin. Rich vegetation, plenty of sunny days a year, good botanical composition of natural meadows and pastures, autochthonous species of domestic animals, indigenous technology of cheese production, milk cream, hard cheese and dry-cured meat represent the available potential (Babovic, 2008). Introduction of meat geographic origin mark will improve export competitive position. Work on breed selection and wider application of selected breeds is necessary in production. Organized approach in terms of expertise and economics may have beneficial influence on autochthonous species development and expansion. Organization of organic agriculture can provide quality products for domestic needs and export can generate profit for farmers and protect the environment. However, livestock production is disorganized, of uneven quality, with little value for hygiene, and has no organized market, processing facilities, state development and economic strategy.

\section{PROCESSING INDUSTRY COMPETITIVENESS}

Agricultural products, fruit and livestock are processed before their final consumption. Processing industry connects agricultural production and the market, and its development goals are to increase manufacturing productivity and efficiency in production and development of high-final products assortment, competitive in foreign markets (Ignjatijević and Milojevic, 2010). In order for products to be competitive, it is necessary to rationally use the processing capacity and raw materials and to produce, with minimal costs, quality products that are competitive for export in foreign markets. It is necessary to establish internal economy in business operations, to rationally organize work process, maximize the production of final products with standard minimum investments and, on this basis, to achieve maximum efficiency and profitability in product unit production, and thus achieve adequate competition in the market.

Researches showed that our own technology is not disposed of; transfer of foreign technologies and technological solutions for development of high quality products is slow, so that out of agricultural products, we get modest assortment of processed units. The world today produces thousands of products from cereals, industrial crops, fruit and grapes, and we produce a modest range of food products. For example, over fifty products are manufactured from raspberries, and we export them in fresh and frozen state only. Over 1000 products are manu- factured from wheat and maize products, and we produce about ten of this. All this speaks about our technical, technological, scientific and developmental retardation.

Data reveal falling back in investment, food industry range development and lack of international market research. Oversized and outdated facilities for processing, investment, innovation and knowledge are the limitating factors in manufacturing high-quality final products for export in competitive world market. Low capacity utilization is conditioned by lack of quality raw materials. Unevenly equipped food industry facilities are characteristic. Besides the present shortcomings, construction capacities and the level of technical and technological equipment is not a limitative development factor. The aim is to exploit existing and new knowledge, introduce innovations, develop new biotechnology and create a good quality, diversified and certified range, improve management and marketing in business activeties and use the comparative advantage of ecological resources in gaining finished products' comparative advantages in the world market.

Food industry is the basis for development, natural continuation of the finalization of agricultural products and a link with the world market. The available processing capacity and existing expansion of small processing capacities are developmental and comparative advantage of agriculture in the international market. Further modernization of technological processes and adjustment of assortment for demand in foreign markets is necessary. Current low utilization of processing capacity, lack of raw material and undeveloped quality assortment in processing adversely affects the export competitiveness (Kotler, 2006.). The current condition restricts competition in the world market, so, it is necessary to analyze the situation in processing area and define the type and quality of products to be placed in foreign markets. The limitative factors of greater competitiveness in the international market are:

1. Poor range of food products as compared to that in developed countries.

2. Neglected research aiming at better use of raw materials and capacities by introducing new lines and products based on the main incidental and secondary raw materials.

3. No application of existing achievements and innovations in processing.

4. Product quality oscillation due to lack of application of product quality standards.

5. Slow adjustment to market criteria for business operations and the absence of modern marketing and management introduction in creating and selling products for exports.

6. Inadequate cooperation between creative experts and agricultural producers. 
It is necessary for agricultural producers to increase productivity and efficiency in production; provide a satisfactory quality of raw materials and to offer, beside traditional products, the products from ecological systems production. It is necessary to improve the organization and integral relationship between production and processing.

Food industry should ensure rational use of agricultural products, a wider range of quality, health safety products, and in line with demand, satisfy consumers' desires and needs in the foreign markets.

\section{AGRICULTURAL-FOOD PRODUCTS' MARKET}

In Serbia, the market of agricultural products has characteristics of a perfectly competitive market on the supply side, and characteristics of oligopoly on the demand side. Agricultural products market is disorganized, competition is underdeveloped and economic relations between agricultural production and processing are impaired (Cvijanovic et al., 2009). On the market, there is disorganization of purchase, manufacturers and processors. The HACCP certification and other quality certificates are earned by a small number of producers. Agriculture products supply in the market is not adequate, both in quantity and quality.

Characteristics of agricultural products' market are limitative factors of agricultural production development and export increase. A large number of producers own small pieces of land, are of unfavourable age and educational structure, have limited economic power and no competitive quality and production size. Production batches are small-scaled and their contact with distributors is inadequate. Due to fragmented production, inadequate and variable supply both in quantity and quality, modest design and packaging, products have uncertain sale in the international market. Certified products are missing and a small number of products are adjusted to new international standards.

Food safety and quality are of particular importance production and distribution. The EU standards on inclusion of food in food chain are the strictest in the world, and all products in the market are subjected to them. Obligation of the manufacturer is to offer quality products in accordance with hygiene regulations (Cvijanovic and Mihailovic, 2010).

The competitiveness of Serbian agriculture in the international level depends on the use of technical and technological engineering, consultation and transfer of foreign and domestic technologies. Through technical and technological engineering, the placement of technology and complete plants for a particular production becomes possible. Taking into consideration the possibility of transferring knowledge and technology, it is necessary to point out that successful results may be achieved when we manage our own technology, technical and technological solutions, and creative professsionals.

Production export orientation includes: stable production structurally adapted to demand, and raising of competitiveness level of products intended for export. In the structure of Serbian exports, there are raw materials, labor-intensive products and other products from the lower processing stages, which have lower unit values. There are fewer technology-intensive products with high unit value.

In the international market, a small number of products are quality competitive. These are agricultural products of low added value, where exported quantities are greater than the imported ones. In the international markets, there is a reduction of price-competitive products, indicating that cheaper agricultural products from Serbia could not compete with bidders from other countries. Regarding export products, price competitive products are food, beverages and raw materials.

Quality competitive agricultural and food products for export are: canned, chilled, frozen, blanched, dried, mixed and dried fruits and vegetable products. It is necessary to continually work on the increase of productivity, production quality, scope and structure of production, development of quality finished products, change of export structure in line with demand and to increase the competitiveness of export by rational use of comparative advantages in export.

High quality is achieved in export of frozen raspberries and fruits. It is necessary to develop a raspberry and other fruits finalization level with the aim of increasing profits. Increasing the production of dehydrated and frozen vegetables, while retaining the standards, has led to export increase of vegetable and its products. It is essential to encourage the development of livestock production with an appropriate economic policy, in order to eliminate deficit and valorization of primary products, and development of the final assortment of meat and meat manufactured products with geographical indications, provide a significant increase in exports and economic effects.

\section{CONCLUSION}

Agricultural production has not been focused on optimal utilization and preservation of available production capacity, increase of production size, changes in production structure in favor of manufacturing products for export, and production of high-final and high quality products. Overall efficiency and productivity of agriculture, with insufficient application of existing and development of new knowledge and technology, limit the agriculture efficiency, technological restructuring and production productivity growth. 
In the development of agricultural production, there ought to be change in program approach to the strategic product development, in terms of agro-ecological conditions and the possibility of agricultural and food products sale in foreign markets.

With the application of new knowledge, investments and technology, it is possible to rationally use available resources, to significantly increase productivity and efficiency in production and thus, improve competitiveness in the world market.

\section{Acknowlegement}

Paper work is a part of the project researches III - 46006 - Sustainable agriculture and rural development in function of Republic of Serbia strategic goals achievement within the Danube region, financed by the Ministry of Education and Science of Republic of Serbia.

\section{REFERENCES}

Babovic J, Lazić B (2005). Agribusiness in organic food production, Monograph, Institute ofFood and Vegetable Crops, Novi Sad, pp.100150.

Babovic J (2008). Marketing and Agromarketing Faculty of Economics and Engineering Management, Novi Sad. pp. 50-55.
Cvijanović, Drago, Mihailović Branko and Simonović, Zoran (2009). The role and significance of marketing in development of Serbian agrarian sector, Monograph, Institute of Agricultural Economics, Belgrade, pp.10-40.

Cvijanovic D, Mihailovic B (2010). Management and marketing of service sector, Institute Agric. Econ. Belgrade. pp. 20-30.

Ignjatijević S, Milojevic I (2010). Economics aspects of Serbian comparative advantages in exports of vegetable matter. Agric. Econ., Belgrade. 20-70.

Kotler F (2006). Marketing management, analysis, planning, implementation and control, Belgrade. 